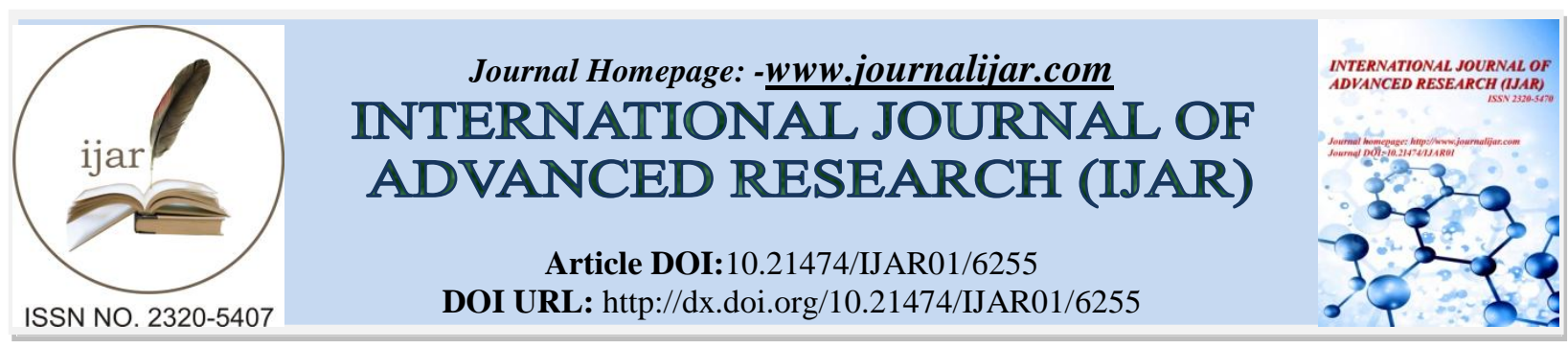

RESEARCH ARTICLE

\title{
IN-VITRO SCREENING OF ANTIFUNGAL ACTIVITY OF CYANOBACTERIAL EXTRACTS AGAINST SOME PHYTOPATHOGENIC FUNGI.
}

\author{
D. K. Shrivastava. \\ Department of Botany and Microbiology, Govt. E. Raghavendra Rao Postgraduate Science College, Bilaspur \\ (Chhattisgarh).
}

\section{Manuscript Info}

Manuscript History

Received: 08 November 2017

Final Accepted: 10 December 2017

Published: January 2018

Key words:-

Antifungal, Cyanobacteria, Phytopathogens, Bio-fungides, Bio-control agents.
Abstract

As a free living diazotrophic prokaryotic microorganism, Cyanobacteria produce a wide array of toxic chemicals and secondary or bioactive metabolites. Allelopathic interactions involving Cyanobacterial flora are being explored for their pharmaceutical and environmental significance. Cyanobacterial allelopathy can be regarded as one of the significant factors influencing their dominance in diverse habitats and as unique producers of a variety of allelochemicals that can be utilized as eco-friendly bio-control agents. In present work detrimental effects of locally isolated Cyanobacterial strains were evaluated against plant pathogenic three fungal isolates (Fusarium oxysporum, Sclerotium rolfsi and Rhizoctonia solani). It was observed that the crude extracts of four Cyanobacterial isolates (Microcystis aeruginosa, Oscilatoria princeps, Anabaena anomala and Nostoc calcicola), were capable of diminishing the growth and further development of phyto-pathogenic fungal isolates. Whereas $M$. aeruginosa showed more antifungal activity compared to other cyanobacterial strains and its Methanol extracts were observed more efficient against local fungal isolates Fusarium oxysporum (\% MI $88.46 \pm 0.24)$ and Sclerotium rolfsii (83.42) as compared to Rhizoctonia solani (78.33). Toxic as well as allelopathic potentialities of cyanobacteria have needed to be further investigation that can offer promising solutions to bio-control against pathogenic microorganisms, providing novel bio-fungicides.

Copy Right, IJAR, 2018,. All rights reserved.

\section{Introduction:-}

Agriculture in Chhattisgarh is an important economic sector, most of the population living on its revenues. The most common crop of this state is paddy, so called 'Dhan Ka Katora'. Consequently Fungi are the main responsible agents for losses in agriculture and horticulture that can infect any part of the plant [1]. The fight against these fungi is based on the use of chemical pesticides. However, chemical pesticides sprayed into the air or discharged into the soil can be harmful to the environment and to humans as well.

After Green Revolution enormous progress with modern irrigation and fertilizer application has been made. The concern of pesticide/fungicide use with respect to human health and environment has brought increasing interest in alternatives by avoiding negative effects on the environment. Cyanobacteria are known to produce intracellular and 
extracellular metabolites with diverse biological activities such as antialgal, antibacterial, antifungal and antiviral activity [2][3][4]. Secondary metabolites from cyanobacteria are associated with toxic, hormonal, antineoplastic and antimicrobial effects [5]. Recently algae are one of the chief biological agents that have been studied for the control of plant pathogenic fungi, particularly soil-borne disease [6]. Cyanobacteria and eukaryotic algae produce bio-active compounds that have antifungal and antibacterial activity [7] against plant pathogens. Allelopathic impact of Cyanobacteria on pathogenic fungi was also studied [8]. Secondary metabolites influence other organisms in the vicinity and are thought to be of phylogenetically important. Kulik (1995)stated a number of reasons, Cyanobacteria and algae are suitable candidates for exploitation as bio-control agents of plant pathogenic fungi. The potential for using Cyanobacteria is the bio-control of plant pathogenic bacteria and fungi. Tiwari \& Sharma (2013) [9]has observed the antifungal activity of Anabaena variabilis against plant pathogens. Screening of Cyanobacteria for antibiotics has opened a new horizon for discovering new drugs. Exploring antifungal efficacy of Cyanobacteria to control plant pathogenic fungi can prove to be an excellent option as they are easy to grow with minimum nutrients, cost effective, no side effects and environment friendly. This work describes the antifungal effect of Cyanobacterial isolates against phytopathogenic fungi.

\section{Materials and Methods:-}

Isolation and identification of microbes:-

For the selection of the experimental materials different species of Cyanobacteria and Fungi were isolated applying proper media and methods. Identification of isolated microbes was completed by microscopic observation.

\section{Cyanobacteria:-}

Soil samples were collected from various agro-fields of Bilaspur division. The samples were brought to laboratory in plastic vials /zipped polythene bag and washed with distilled water to prevent potential contaminants. Isolation of Cyanobacterial strain was performed in specific nutrient media (Allen \& Arnon, BG-110 and Chu-10) and was stored as suspension culture in growth medium under prescribed condition [10] [11]. Isolated strains were identified by microscopic observation with the help of Key standardized by Desikachary (1959) and Anand (1989) [12, 13].

\section{Fungal strains:-}

The fungal strains were isolated from agronomic soil samples. They were grown in the laboratory in suitable media such as Potato dextrose agar media (PDA) and Sabouraud's agar media and fungal isolates were identified on the basis of morphological characteristics by microscopic observation. Taxonomic guides [14] were used to identify the isolated fungal culture.

\section{Extraction:-}

Axenic culture of Cyanobacterial isolates were raised in growth cabinet under laboratory condition. At the stationary phase of growth (approximately 30 days), Cyanobacteria biomass were harvested by centrifugation and dried in a hot air oven at $50^{\circ} \mathrm{C}$ over night. The dried biomass $-2 \mathrm{~g} / 25 \mathrm{ml}(\mathrm{w} / \mathrm{v})$ of Cyanobacteria were extracted with $75 \%$ methanol and ethanol (HPLC grade). The extracts were sonicated for 20 min using ultrasonic micro-tip probe of 400 watt and centrifuged at $5000 \mathrm{rpm}$ for $10 \mathrm{~min}$. Supernatant was retained and the pellet re-extracted as before three times. Combined supernatant was evaporated to dryness at $40^{\circ} \mathrm{C}$ using rotary evaporator. Dried extracts were stored in labeled sterile vials in a refrigerator till further use [15].

\section{Toxicity assessment:-}

For testing the antifungal activities of crude extract of Cyanobacteria against identified fungal isolates with the help of laboratory methods and Carbendazim and Mancozeb (as fungicides) were used as control. The following method had been employed to confer the toxicity of crude extract of different Cyanobacterial isolates on identified bacteria $\&$ fungi.

\section{Percent mycelial inhibition:-}

Petri plates with medium were aseptically inoculated at the centre with mycelia disc of $5 \mathrm{~mm}$ diametertaken from $96 \mathrm{hrs}$ old culture. Plates were then incubated at $26 \pm 1^{\circ} \mathrm{C}$ in BOD incubator and mycelial growth pattern was observed. Radial diameter was recorded twice perpendicularly after 96 hrs incubation using a transparent millimeter ruler. Percentage inhibition of mycelia growth was calculated. 


\section{Results and Discussion:-}

Through examination of samples total 16 species of Cyanobacteria were isolated, out of which nine heterocystous form and seven non-heterocystous forms were identified as nitrogen fixing and non nitrogen fixing strains respectively (Table -1, Plate -1; Fig. - I to XVI).

Table - 1: Morphologically dissimilar Cyanobacteria isolated during the survey.

\begin{tabular}{|c|c|c|}
\hline Thallus & Non Nitrogen fixing & Nitrogen fixing \\
\hline Unicellular & $\begin{array}{l}\text { 1. Aphanocapsa elachista } \\
\text { 2. Aphanothece saxicola }\end{array}$ & NIL \\
\hline Colonial & 3. $\quad$ Microcystis aeruginosa & NIL \\
\hline Filamentous & $\begin{array}{ll}\text { 4. } & \text { Lyngbya birgei } \\
5 . & \text { Lyngbya shackletoni } \\
6 . & \text { Oscillatoria princeps } \\
\text { 7. } & \text { Oscillatoria cortiana }\end{array}$ & $\begin{array}{l}\text { 8. Anabaena oryzae } \\
\text { 9. Anabaena anomala } \\
\text { 10. Anabaena unispora } \\
\text { 11. Aulosira prolifica } \\
\text { 12. Calothrix elenkinii } \\
\text { 13. Cylindrospermum indicum } \\
\text { 14. Gloeotrichia echinulata } \\
\text { 15. Nostoc calcicola } \\
\text { 16. Nostoc ellipsosporum }\end{array}$ \\
\hline
\end{tabular}

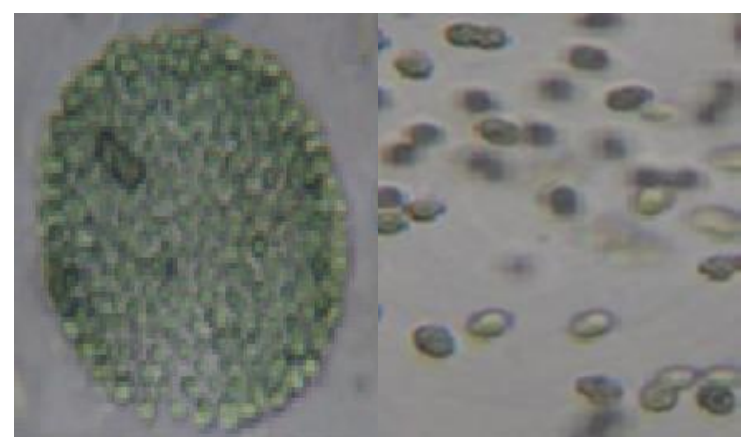

Fig.-I[AphaenocapsaFig.-II[Aphanothece elachista] saxicola]aeruginosa]birgei]

Fig.-V[LyngbyaFig.-VI[OscillatoriaFig.-VII[OscillatoriaFig.-VIII[Anabaena shackletoni]

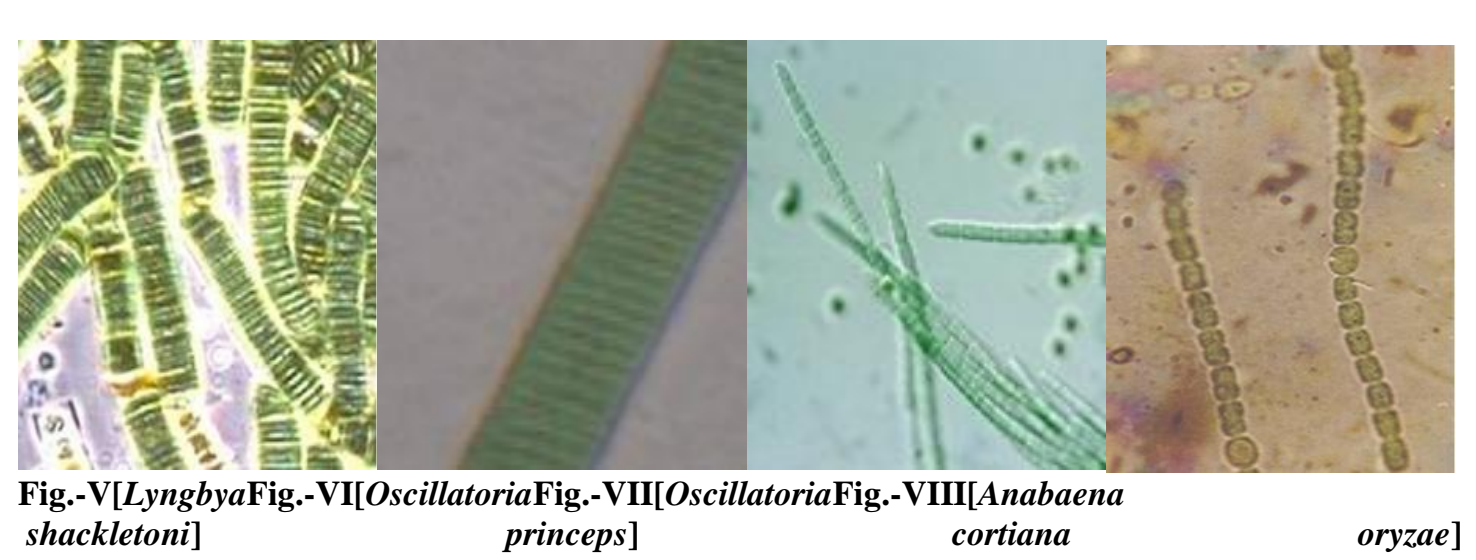

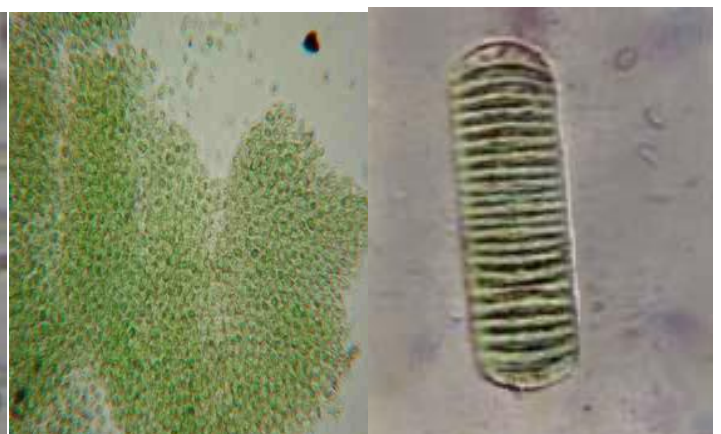

Fig.-III[MicrocystisFig.-IV[Lyngbya 


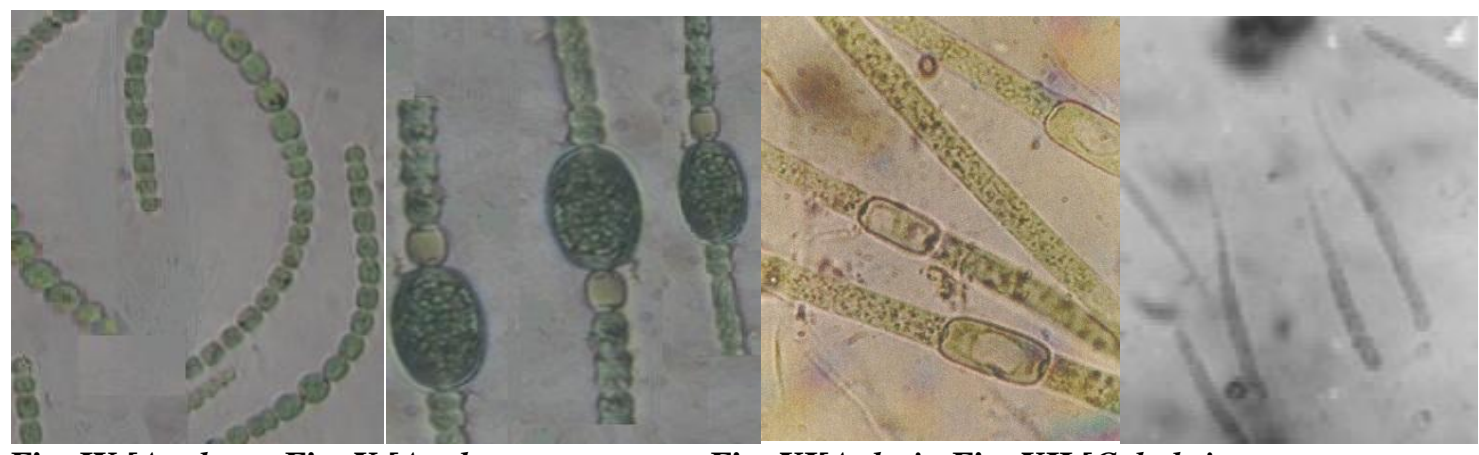

Fig.-IX [AnabaenaFig.-X [Anabaena anomala]unispora]prolifica]

Fig.-XI[AulosiraFig.-XII [Calothrix elenkinii]

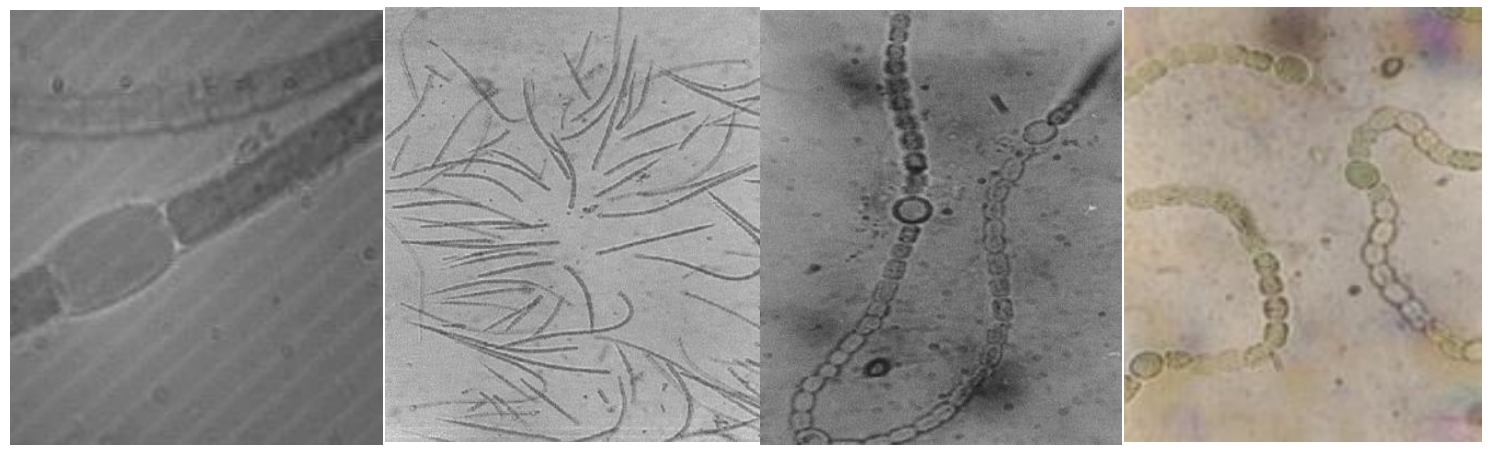

Fig.-XIII[CylindrospermumFig.-XIV[GloeotrichiaFig.-XV[Nostoc Fig.-XVI[Nostoc indicum] echinulata]

calcicola] ellipsosporum]

Plate - 1: Fig.- I - XVI

Simultaneously total 6 fungal species (Aspergillus niger, Penicillum notatum, Mucor sp., Sclerotium rolfsii, Fusarium oxysporum and Rhizoctonia solani) were isolated and identified on the basis of their morphological features (Table -2, Plate -2; Fig. - I to VI).

Table 2:-Characteristic features of fungal isolates.

\begin{tabular}{|c|c|c|l|}
\hline $\begin{array}{c}\text { Name Of } \\
\text { Fungi }\end{array}$ & $\begin{array}{c}\text { Taxonomic } \\
\text { Status }\end{array}$ & Colour & \multicolumn{1}{c|}{ Microscopic Observation } \\
\hline $\begin{array}{c}\text { Aspergillus } \\
\text { niger }\end{array}$ & Ascomycetes & $\begin{array}{c}\text { dark to pale yellow in early stage } \\
\text { while became black at maturity }\end{array}$ & $\begin{array}{l}\text { Jet black conidia, reverse usually grey, spherical } \\
\text { conidia, rough with maturity. }\end{array}$ \\
\hline $\begin{array}{c}\text { Penicillium } \\
\text { notatum }\end{array}$ & Ascomycetes & $\begin{array}{c}\text { velvety or woolly colonies } \\
\text { initially white and become green }\end{array}$ & $\begin{array}{l}\text { Conidiophore green in colour, repeatedly branched, } \\
\text { brushy head. }\end{array}$ \\
\hline $\begin{array}{c}\text { Mucor sp. } \\
\text { filamentous colonies, fluffy } \\
\text { appearance, white in colour } \\
\text { rolfsii }\end{array}$ & Zygomycetes & $\begin{array}{l}\text { Globular sporangia round black in colour that was } \\
\text { supported by elevated column like columella. Non- } \\
\text { septate or partially septate hyphae . }\end{array}$ \\
\hline $\begin{array}{c}\text { Fusarium } \\
\text { oxysporum }\end{array}$ & Ascomycetes & $\begin{array}{c}\text { It was characterized as felty } \\
\text { white appearance }\end{array}$ & $\begin{array}{l}\text { Silky white hyphae tend to aggregate into } \\
\text { rhizomorphic cord as well as characteristic } \\
\text { sclerotium - fan shape was found. }\end{array}$ \\
\hline $\begin{array}{c}\text { Rhizoctonia } \\
\text { solani }\end{array}$ & Basidiomycetes & $\begin{array}{l}\text { Moist appearance, red with cottony and orange } \\
\text { brown mycelium, with light brown exudates hyphen } \\
\text { septet, small conidia in chain, sickle shaped long } \\
\text { conidia were also observed. }\end{array}$ \\
\hline
\end{tabular}




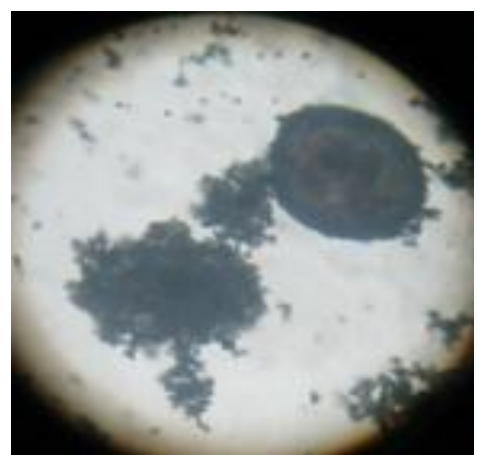

Fig.-I: Aspergillus niger

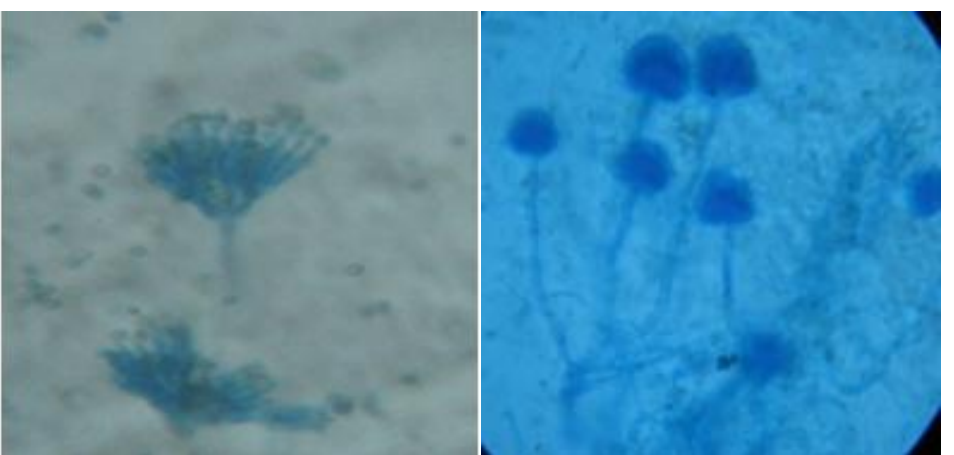

Fig.-II: Penicillium notatumFig.-III: Mucor sp.

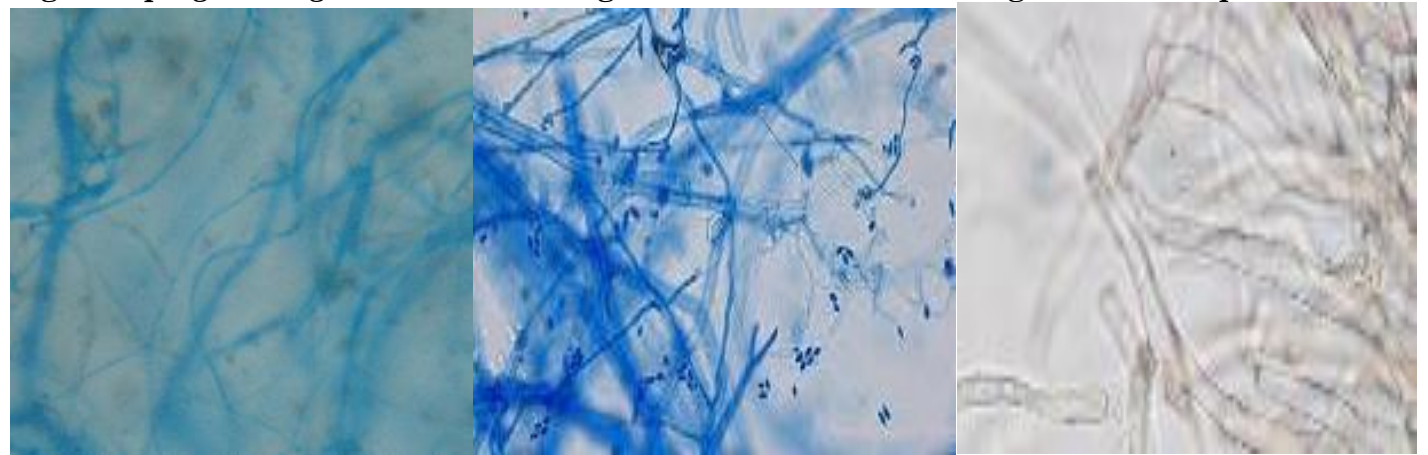

Fig.-IV: Sclerotium rolfsiiFig.-V: Fusarium oxysporumFig.-VI: Rhizoctonia solani Plate- 2: Fig I - VI

On the basis of toxic potentiality of crude extracts two non- heterocystous ( Microcystis aeruginosa \&Oscillatoria princeps) and two heterocystous (Nostoc calcicola \& Anabaena anomala) cyanobacterial isolates were selected for further experiment in view of the assessment of the antifungal effect of Cyanobacterial isolates on three Fungal isolates (Fusarium oxysporum, Sclerotium rolfsii and Rhizoctonia solani). The data of percent mycelia inhibition and concerned graph indicated that the extract of Microcystis aeruginosa have great potential as fungicides carbendazim and Mancozeb compound against pathogenic fungi which was tested (Table - 3, plate -3; Fig. I - IV.). Toxic potentiality of Nostoc calcicola was found lesser than Oscilatoria princepsbut greater than other cyanobacterial isolates, whereas minimum potentially of growth inhibition was observed in case of Anabaena anomala.

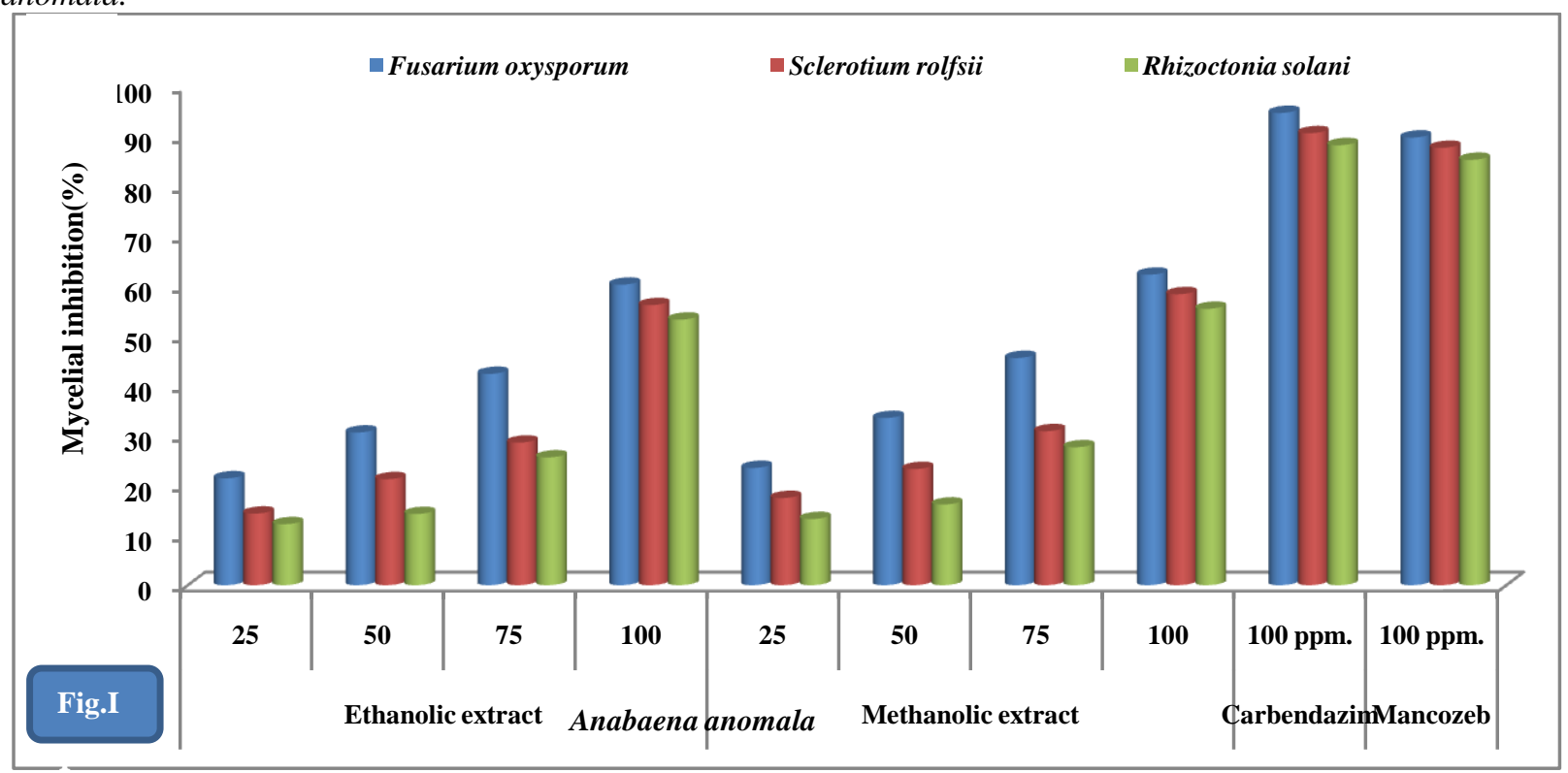



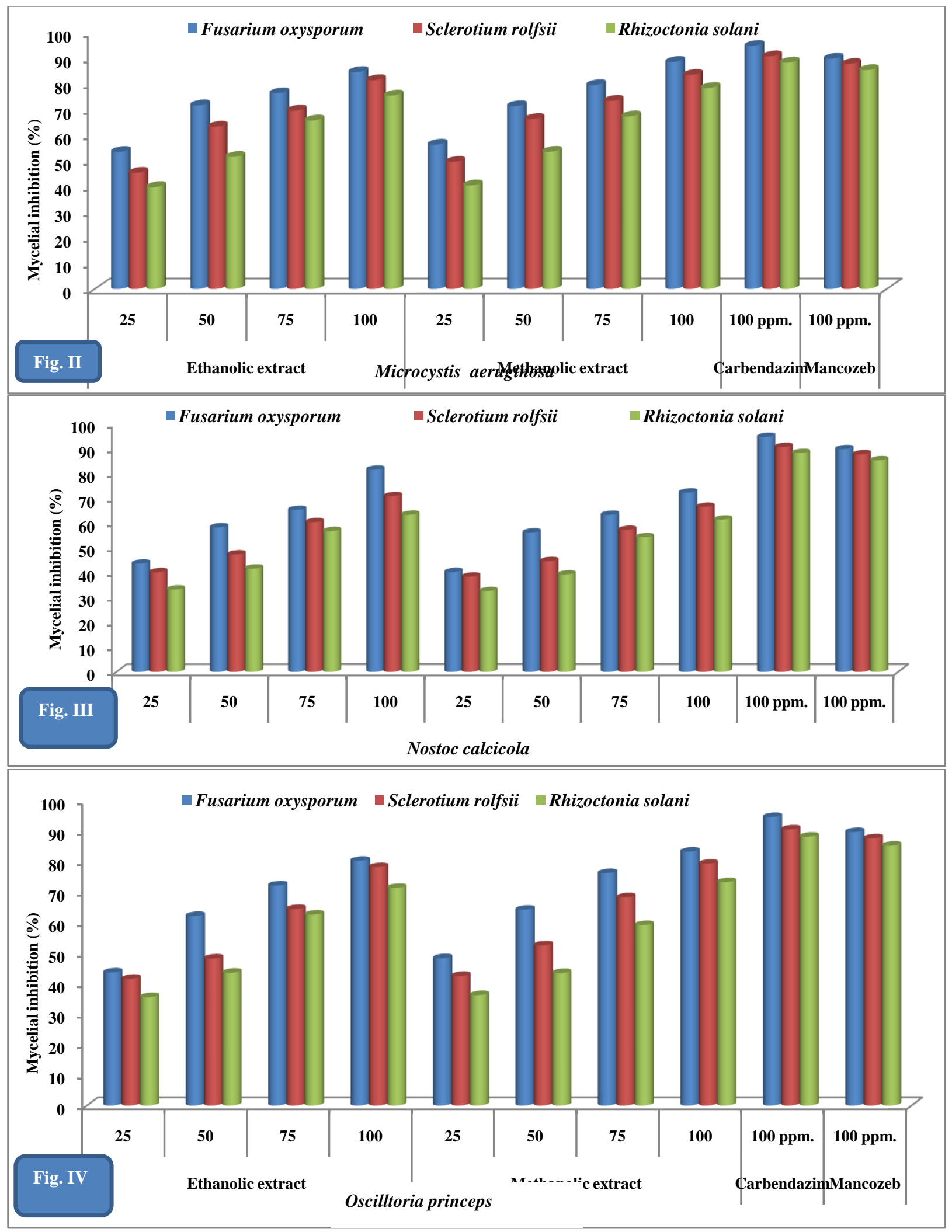

Plate- 3: Fig I - IV

Table 3:- Effect of crude extracts of Cyanobacterial isolate on growth of Fungal isolates (Fusarium oxysporum, Sclerotium rolfsii and Rhizoctonia solani). 


\begin{tabular}{|c|c|c|c|c|c|}
\hline \multirow{2}{*}{ 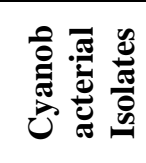 } & \multirow[b]{2}{*}{ Crude extracts } & \multirow{2}{*}{ 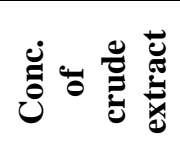 } & \multicolumn{3}{|c|}{$\begin{array}{c}\text { Percent of Mycelial Inhibition } \\
\text { (Mean value } \pm \text { SD) }\end{array}$} \\
\hline & & & $\begin{array}{c}\text { Fusarium } \\
\text { oxysporum }\end{array}$ & Sclerotium rolfsii & $\begin{array}{l}\text { Rhizoctonia } \\
\text { solani }\end{array}$ \\
\hline \multirow{8}{*}{ 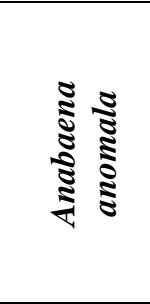 } & \multirow{4}{*}{$\begin{array}{r}\text { Ethanol } \\
\text { extract }\end{array}$} & 25 & $21.42 \pm 0.25$ & $14.35 \pm 0.18$ & $12.23 \pm 0.22$ \\
\hline & & 50 & $30.61 \pm 0.32$ & $21.25 \pm 0.43$ & $14.27 \pm 0.52$ \\
\hline & & 75 & $42.37 \pm 0.27$ & $28.58 \pm 0.26$ & $25.62 \pm 0.35$ \\
\hline & & 100 & $60.25 \pm 0.22$ & $56.16 \pm 0.15$ & $53.24 \pm 0.28$ \\
\hline & \multirow{4}{*}{ Methanol extract } & 25 & $23.51 \pm 0.24$ & $17.48 \pm 0.35$ & $13.26 \pm 0.26$ \\
\hline & & 50 & $33.52 \pm 0.22$ & $23.28 \pm 0.43$ & $16.17 \pm 0.52$ \\
\hline & & 75 & $45.56 \pm 0.26$ & $30.88 \pm 0.36$ & $27.65 \pm 0.41$ \\
\hline & & 100 & $62.25 \pm 0.33$ & $58.35 \pm 0.38$ & $55.41 \pm 0.29$ \\
\hline \multirow{8}{*}{ 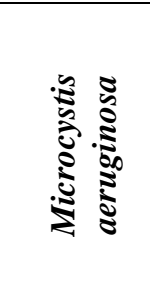 } & \multirow{4}{*}{$\begin{array}{r}\text { Ethanol } \\
\text { extract }\end{array}$} & 25 & $53.37 \pm 0.32$ & $45.25 \pm 0.24$ & $39.67 \pm 0.25$ \\
\hline & & 50 & $71.56 \pm 0.16$ & $63.21 \pm 0.23$ & $51.45 \pm 0.21$ \\
\hline & & 75 & $76.24 \pm 0.34$ & $69.51 \pm 0.28$ & $65.66 \pm 0.19$ \\
\hline & & 100 & $84.52 \pm 0.35$ & $81.34 \pm 0.42$ & $75.35 \pm 0.28$ \\
\hline & \multirow{4}{*}{ Methanol extract } & 25 & $56.23 \pm 0.42$ & $49.52 \pm 0.34$ & $40.34 \pm 0.27$ \\
\hline & & 50 & $71.24 \pm 0.36$ & $66.23 \pm 0.45$ & $53.45 \pm 0.28$ \\
\hline & & 75 & $79.43 \pm 0.27$ & $73.34 \pm 0.35$ & $67.28 \pm 0.32$ \\
\hline & & 100 & $88.46 \pm 0.24$ & $83.42 \pm 0.28$ & $78.33 \pm 0.45$ \\
\hline \multirow{8}{*}{ 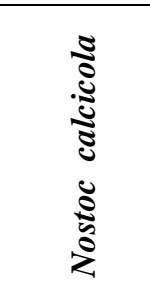 } & \multirow{4}{*}{$\begin{array}{r}\text { Ethanol } \\
\text { extract }\end{array}$} & 25 & $43.65 \pm 0.35$ & $40.18 \pm 0.43$ & $33.21 \pm 0.56$ \\
\hline & & 50 & $58.25 \pm 0.32$ & $47.32 \pm 0.24$ & $41.62 \pm 0.29$ \\
\hline & & 75 & $65.28 \pm 0.32$ & $60.35 \pm 0.46$ & $56.75 \pm 0.34$ \\
\hline & & 100 & $81.52 \pm 0.25$ & $70.81 \pm 0.21$ & $63.33 \pm 0.33$ \\
\hline & \multirow{4}{*}{ Methanol extract } & 25 & $40.25 \pm 0.17$ & $38.4 \pm 0.25$ & $32.56 \pm 0.21$ \\
\hline & & 50 & $56.18 \pm 0.42$ & $44.67 \pm 0.16$ & $39.28 \pm 0.32$ \\
\hline & & 75 & $63.3 \pm 0.32$ & $57.23 \pm 0.18$ & $54.28 \pm 0.15$ \\
\hline & & 100 & $72.26 \pm 0.26$ & $66.53 \pm 0.34$ & $61.36 \pm 0.42$ \\
\hline \multirow{8}{*}{ 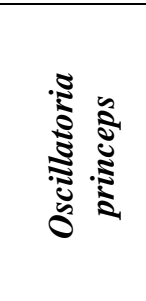 } & \multirow{4}{*}{$\begin{array}{r}\text { Ethanol } \\
\text { extract }\end{array}$} & 25 & $43.65 \pm 0.23$ & $41.56 \pm 0.28$ & $35.57 \pm 0.23$ \\
\hline & & 50 & $62.21 \pm 0.35$ & $48.26 \pm 0.27$ & $43.55 \pm 0.26$ \\
\hline & & 75 & $72.24 \pm 0.44$ & $64.51 \pm 0.35$ & $62.66 \pm 0.45$ \\
\hline & & 100 & $80.32 \pm 0.35$ & $78.24 \pm 0.42$ & $71.44 \pm 0.28$ \\
\hline & \multirow{4}{*}{ Methanol extract } & 25 & $48.35 \pm 0.15$ & $42.51 \pm 0.35$ & $36.23 \pm 0.22$ \\
\hline & & 50 & $64.25 \pm 0.12$ & $52.56 \pm 0.17$ & $43.45 \pm 0.25$ \\
\hline & & 75 & $76.27 \pm 0.27$ & $68.33 \pm 0.35$ & $59.23 \pm 0.32$ \\
\hline & & 100 & $83.34 \pm 0.34$ & $79.36 \pm 0.28$ & $73.31 \pm 0.45$ \\
\hline \multicolumn{3}{|c|}{ Solvent control } & $\mathbf{0}$ & $\mathbf{0}$ & $\mathbf{0}$ \\
\hline \multicolumn{6}{|c|}{ Fungicides } \\
\hline \multicolumn{2}{|c|}{ Carbendazim } & 100 ppm. & $94.70 \pm 0.13$ & $90.64 \pm 0.16$ & $88.23 \pm 0.17$ \\
\hline \multicolumn{2}{|c|}{ Mancozeb } & 100 ppm. & $89.76 \pm 0.21$ & $87.70 \pm 0.24$ & $85.29 \pm 0.36$ \\
\hline
\end{tabular}

During present course of investigation, the results obtained regarding Cyanobacterial toxicity, revealed that the growth of all three fungal isolates were inhibited when subjected to crude extracts (Ethanol or Methanol) on solid nutrient media. Growth inhibition potency of crude extracts of cyanobacterial isolates have also been compared with standard fungicides against mycelial growth. The result of toxic potentiality as obtained against fungal pathogens has also been supported the findings. Cyanobacteria produce biologically active compounds that have allelopathic and toxic activity against plant pathogens [16][17]. Kim and Kim (2008) [18] reported inhibition of F.oxysporum f. sp. lycopersici by extracts of $N$. commune FA-103. Biological control of Fusarium oxysporum f. sp. lycopersici (FOL) causing wilt disease of tomato was studied in vitro as well as under pot conditions and was concluded that $N$. linkia, can be utilised for the biological control of wilt disease of tomato which may help to obtain a higher yield and good health in agriculture [19]. Mohamed et al. (2011) investigated the suppression effect of cyanobacterial speciesNostoc endophytum and Nostoc muscurum against, the causal agent of Soya bean root rot Rhizoctonia solani.

The present research work correlates the findings of various workers as reported earlier regarding concerned research work. In this study Cynobacteria showed significant antifungal activities. This kind of investigation produces a much generalized view that Cynobacteria are capable of inhibiting growth of fungal pathogens. This work focuses on the ability of Canobacteria to be used as biocontrol agent further studies on Cyanobacterial 
metabolites are essential for scientific workers to identify the toxic impact on phytopathogenic fungi which may lead to the formulation of significant bio-active compounds of biological origin, such as biofungicides.

\section{Acknowledgment:-}

Author is thankful to the Principal, Govt. E. Raghavendra Rao Postgraduate Science College, Bilaspur (C.G.) for providing research facilities and encouragement to carried out the present investigation.

\section{References:-}

1. Messiaen C. M., Blancard, D., Rouxel, F., Lafon, R. Les maladies des plantes maraîchères. Paris: INRA; 1991. p. 552 .

2. Mohamed El-anwar H. Osman, Mostafa M. El-Sheekh, Metwally A. Metwally, Abd El whab A. Ismail and Mona M. Ismail (2011): Antagonistic Activity of Some Fungi and Cyanobacteria Species against Rhizoctonia solani. International Journal of Plant Pathology Vol.2; Pp- 101-114.

3. Shrivastava, D. K. and Saluja, T. (2012): Antibacterial properties of exo-toxins released by CyanobacteriaPhormediumcalcicola and Oscillatoriaprinceps isolated from Bilaspur (C. G.). National Journal of life Science. Vol. 09, Pp. - 229-231.

4. Shrivastava, D. K.; Mishra, R. and Chandra T. P. (2014): Evaluation of Cyanobacterial toxicity against corresponding field soil Bacteria. International Journal of Pharmacy \& Life Sciences Vol- 5(7) Pp-3694-3700.

5. Yadav, Shweta, Sinha, R. P., Tyagi, M. B. and Kumar, Ashok (2011) Cyanobacterial secondary metabolites. Int J Pharm Bio Sci. 2(1): (B) 144-167.

6. Hewedy, M. A., Rhhal, M.M.H. and Ismail, I. A. (2000): Pathological studies on soyabean damping off disease. Egypt J. Applied Sci. Vol. 15; Pp-88-102.

7. Kulik, M. M.(1995): The potential for using cyanobacteria (blue-green algae) and algae in the biologicalcontrol of plant pathogenic bacteria and fungi. Eur. J. Plant Pathol.Vol.101; Pp-585-599.

8. Tiwari, A. and Kaur, A. (2014): Allelopathic impact of Cyanobacteria on pathogenic fungi. Int. J. Pure App. Biosci. Vol. 2(3); Pp-63-70.

9. Tiwari, A. and Sharma, A. (2013): Antifungal activity of Anabaena variabilis against plant pathogens. International Journal of Phrma and Biosciences. Int J Pharm Bio Sci. Vol. 4; Pp-1030-1036.

10. Shrivastava, D. K. (2000): Cyanobacteria from paddy fields of Durg district of Chhattisgarh State. Phycos. Vol. 39(1\&2), p-125-128.

11. Shrivastava, A.K.; Pandey, F. K. and Shrivastava, D. K. (2005): Nitrogen fixing cyanobacteria flora and properties of paddy field soils of four districts of Chhattisgarh state. Nat. J. Life Sc. 2(Supp.), p-501-506

12. Desikachary, T.V. (1959, 1972):Cyanophyta. Pub. Indian Council of Agricultural Research New Delhi.

13. Anand, N. (1989): Hand book of Blue Green Algae. Pub. Bisen Singh and Mahendrapal Singh. Dehradun.

14. Alexopopulus, C. J.; Mims, C. W. and Bleckwell, M. (1996): Introductory Mycology $4^{\text {th }}$ Edt. John wiley and Sons, New York, USA.

15. Chauhan A, Chauhan G, Gupta P, Goyal P and Kaushik P. In vitro antibacterial evaluation of Anabaena sp. against several clinically significant microflora and HPTLC analysis of its active crude extracts. Indian J. Pharm., 2010; 42:105-107.

16. Bonjouklian, R. Smitka, T.A., Doolin, L. E. Molloy, R. M., Deebono, M. Shaffer, S. A., Moore, E., Stewart, J.B. Patterson, G.M.L. (1991): Tjipanazoles, new antifungal agents agents from the blue-green algae Tolypothrix tjipansensis. TetrahedronVol. 47; Pp-7739-7750.

17. Kiviranta, J. Abdel-Hameed, A. Sivonen, K. Niemelä, S.I. Carlberg, G.(2006): Toxicity of cyanobacteria to mosquito larvae- screening of active compounds. Envrion. Toxicol. Water Qual. Vol. 8; Pp-63-71.

18. Kim, J. Kim, J.D.(2008): Inhibitory effect of algal extracts on mycelia growth of the tomato-wilt pathogen,Fusarium oxysporum f. sp. lycopersici. Mycobiol. Vol. 36; Pp- 242-248.

19. Hend A. A. and Perveen, K. (2012): Biological control of Fusarium wilt of tomato byantagonist fungi and cyanobacteria. African Journal of Biotechnology. Vol.11; Pp-1100-1105. 